\title{
One Carbon Metabolism in Anaerobic Bacteria: Regulation of Carbon and Electron Flow During Organic Acid Production
}

Grant No. DE-FB02-87ER13719

\section{PR OGR ESS REPOR T}

Period: June, 1990 - May, 1992

\author{
P.I. J. Gregory Zeikus
}

ro-P.I. Mahendra K. Jain

Michigan Biotechnology Institute 3900 Collins Road, P.O. Box 27609

Lansing, MI 48909

\section{DISCLAIMER}

\begin{abstract}
This report was prepared as an account of work sponsored by an agency of the United States Government. Neither the United States Government nor any agency thereof, nor any of their employees, makes any warranty, express or implied, or assumes any legal liability or responsibility for the accuracy, completeness, or usefulness of any information, apparatus, product, or process disclosed, or represents that its use would not infringe privately owned rights. Reference herein to any specific commercial product, process, or service by trade name, trademark, manufacturer, or otherwise does not necessarily constitute or imply its endorsement, recommendation, or favoring by the United States Government or any agency thereof. The views and opinions of authors expressed herein do not necessarily state or reflect those of the United States Government or any agency thereof.
\end{abstract}




\section{SUMMARY OF PROGRESS ON EXPERIMENTAL OBIECTIVES}

A. B. methylotrophicum - a model to understand control of carbon and electron flow in relation to inter- and intra-molecular $\mathrm{H}_{2}$ transfer.

Objective 1: To elucidate the metabolic pathway of solvent production in $B$. methylotrophicum.

We have shown that $B$. methylotrophicum can ferment $\mathrm{CO}$ into ethanol and butanol at low $\mathrm{pH}$ values. We have completed studies which demonstrate that the organism produces an NAD-linked butaldehyde and acetaldehyde reductase and an NAD-linked alcohol dehydrogenase. A manuscript on these studies is being prepared for submission and publication in Appl. Environ. Microbiol.

Objective 2: To characterize and purify hydrogenase in relation to establishment of physiological function.

The effect of $\mathrm{pH}$ on glucose fermentation and hydrogenase activity and pyridine nucleotide ferredoxin oxid oreductase of Butyribacterium methylotrophicum was investigated with an anaerobic continuous culture system. The amount of acetate and butyrate formed and the in vivo levels of hydrogenase and in vitro levels of pyridine nucleotide ferredoxin oxidoreductase were studied under different $\mathrm{pH}$ values for steady-stead growth. The molar ratio of butyrate/acetate was shifted from 0.35 at $\mathrm{pH} 7.0$ to 1.21 at $\mathrm{pH}$ 5.5. Uptake hydrogenase activity and ferredoxin-NAD oxidoreductase increased while production hydrogenase and NADH-ferredoxin oxidoreductase decreased in cells grown at $\mathrm{pH} 5.5$ versus $\mathrm{pH}$ 7.0. The addition of exogenous hydrogen did not increase the butyrate/acetate ratio at $\mathrm{pH} 7.0$ or $\mathrm{pH} 5.5$. The results indicate that growth $\mathrm{pH}$ values regulate both hydrogenase activity and pyridine nucleotide ferredoxin oxidoreductase levels such that at acid $\mathrm{pH}$ values more intermediary electron flow is directed towards butyrate production than $\mathrm{H}_{2}$ production. A manuscript on these studies is being prepared for submission to publication in Appl. Environ. Microbiol.

We have begun studies on cloning the genes for and purification of soluble versus membrane-bound hydrogenase.

B. A. succiniciproducens a model to understand $\mathrm{CO}_{2}$ fixation in relation to control of carbon and electron flow.

Objective 3: Elucidate the biochemical mechanism for metabolic regulation of the succinate fermentation.

This objective has been completed and published (see Samuelov et al., 1991, Appl. Environ. Microbiol. 57:3013-3019). 
$\mathrm{CO}_{2}$ serves as an electron acceptor and a positive regulator of PEP: carboxykinase and a negative regulator of lactate hydrogenase and alcohol dehydrogenase. The PEP carboxykinase functions in catabolic $\mathrm{CO}_{2}$ fixation and $\mathrm{CO}_{2}$ switches glucose metabolism from a fermentative into a respiratory process.

Phosphoenolpyruvate carboxykinase from the obligate anaerobe Anaerobiospirillum succiniciproducens was purified 18-fold. The enzyme was monomeric with an $\mathrm{M}_{\mathrm{r}}$ of $57000 \pm 2000$. The enzyme was oxygen stable and had a $\mathrm{pH}$ optimum of 6.5-7.1 and was stable from $\mathrm{pH} 5.0$ to 9.0. The $\mathrm{N}$-terminal amino acid sequence of the enzyme was compared with the $\mathrm{N}$-terminal sequences from six other phosphoenolpyruvate carboxykinases from different organisms and showed the most similarity to the enzyme from Escherichia coli. The enzyme displayed Michaelis-Menten kinetics for the substrate PEP and the co-substrate bicarbonate with a $K_{m}$ of $0.54 \mathrm{mM}$ and $17 \mathrm{mM}$, respectively. The enzyme required $\mathrm{Mn}^{+2}$ or $\mathrm{CO}^{+2}$ in addition to $\mathrm{Mg}^{+2}$ to exhibit maximum activity. pCMB inhibited activity and PEP protected the enzyme against inactivation suggesting that an essential cysteine may be in the active site. A manuscript on these studies was forwarded to Biochem. J. for publication consideration.

We have begun cloning the PEPCK gene using probes made toward the $\mathrm{N}$ terminal amino acid sequence.

Objective 4: Characterize the electron flow pathway key oxidoreductases and provide evidence for ETP during $\mathrm{CO}_{2}$ reduction to succinate.

In light of our exciting findings above, we have changed this objective to cloning the gene for and characterization of the structure and function of PEP carboxykinase, a key catabolic $\mathrm{CO}_{2}$ fixing enzym, in anaerobes.

C. Heteroacidogens - models to understand the physiobiochemical function of formate metabolism in anaerobes.

Objective 5: Characterization of $\mathrm{CO}_{2}$ reductase a key catabolic $\mathrm{CO}_{2}$ fixing enzyme in anaerobes.

Prior to our studies, $\mathrm{CO}_{2}$ reductase activity was only reported in $\mathrm{C}$. pasteurianum and functions in anabolism not catabolism. We have shown that Sarcina ventriculi produces $\mathrm{CO}_{2}$ reductase but lacks formate dehydrogenase and that the enzyme is used catabolically when cells make high formate levels (i.e., > $30 \mathrm{M}$ ) (see Lowe and Zeikus, 1991, Arch. Microbiol. 155:325-329). Notably, we have detected $\mathrm{CO}$ reductase in methanogens which lack formate dehydrogenase. A manuscript on these studies is prepared for submission to publish in Appl. Environ. Microbiol.

Our attempts to purify the enzyme in cell extracts has failed to date but we continue to attempt this in S. ventriculi, B. methylotrophicum, M. barkeri, and $A$. 
succiniciproducens. Because of the lack of progress on this objective of the grant, we have added the new objectives below.

D. S. ventricali: a model for understanding the influence of low $\mathrm{pH}$ on one carbon metabolism and $\mathrm{C} \& \mathrm{E}$ flow.

We have shown that low $\mathrm{pH}$ " stimulates synthesis of pyruvate decarboxylase in $S$. ventriculi. This causes a shift from formic and acetic production to ethanol production. Pyruvate decarboxylase was the key branch point enzyme regulating the alteration of $C \& E$ flow (see Lowe and Zeikus, Arch. Microbiol. 155:325-329).

Objective 6: Cloning the gene for and characterization of pyruvate decarboxylase structure-function.

The pyruvate decarboxylase from $S$. ventriculi was purified and biochemically characterized (see Lowe and Zeikus, 1992, J. Gen. Microbiol., in press). The enzyme shows closer homology to pyruvate decarboxylase of yeast than Zymomonas.

Nucleotide probes have been made based on the pyruvate decarboxylase N-terminal sequence and DNA fragments which hybridize to the probes have been isolated.

Objective 7: Characterization of membrane structure function properties in relation to growth at $\mathrm{pH} 7.0$ versus 3.0 .

Changes in the composition of membrane lipids in a strictly anaerobic, facultative acidophilic eubacterium, Sarcina ventriculi were studied in response to various forms of environmental stress. Changes in lipid composition and structure occurred in response to environmental $\mathrm{pH}$. At neutral $\mathrm{pH}$, the predominant membrane fatty acids ranged in chain length from C14 to C18. However, when cells were grown at $\mathrm{pH} 3.0$, a family of unique very long chain $\alpha, \omega$-decarboxylic fatty acids containing 32 to 36 carbon atoms were synthesized and accounted for $50 \%$ of the total membrane fatty acids. It is proposed that these unusual fatty acids negate the damage to membrane stability caused by deleterious fermentation products (acetic acid, formic acid, and ethanol) formed during growth. Addition of alcohols, either metabolic $(0.25 \mathrm{M}$ ethanol) and non-

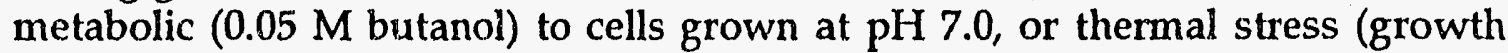
temperature at $\mathrm{pH} 7.0$ was raised from $37^{\circ} \mathrm{C}$ to $45^{\circ} \mathrm{C}$ or $55^{\circ} \mathrm{C}$ ) also resulted in the synthesis of these very long chain fatty acids. Thus, synthesis of these unusual membrane lipids appears to be in response to diverse environmental parameters. Synthesis of these very long chain $\alpha, \omega$-dicarboxylic acids was reversed by returning the temperature back to $37^{\circ} \mathrm{C}$. These more hydrophobic fatty acids may serve to enhance the stability of the membrane by decreasing the degrees of ${ }^{\circ}$ freedom of molecular motions among the membrane components hence 
maintaining the optimal fluidity. A manuscript on these studies has been submitted for consideration and publication in Journal of Bacteriology.

Studies underway will determine if ATPase activity and organic acid uptake or differences in cells are regulated as a function of $\mathrm{pH}$ extremes for growth.

\section{PUBLICATIONS WITH DOE GRANT SUPPORT}

1. Lowe, S., and J. G. Zeikus. 1991. Metabolic regulation of carbon and electron flow as a function of $\mathrm{pH}$ during growth of Sarcina ventriculi. Arch. Microbiol. 155:325-329.

2. Samuelov, N.S., R. Lamed, S. Lowe and J. G. Zeikus. 1991. Influence of $\mathrm{CO}_{2-}$ $\mathrm{HCO}_{3}^{-}$levels and $\mathrm{pH}$ on growth succinate production and enzyme activities of Anaerobiospirillum succiniciproducens. Appl. Environ. Microbiol. 57:3013-3019.

3. Lowe, S., and J. G. Zeikus. 1992. Purification and characterization of pyruvate decarboxylase from Sarcina ventriculi. J. Gen. Microbiol. (in press).

\section{ABSTRACTS}

1. Kemner, J.M., and J. G. Zeikus. 1990. Evidence for Cytochrome $b$ Function in Acetate Catabolism by Methanosarcina barkeri MS. Annual Meeting of the American Society for Microbiology.

2. Wu, W.-M., R. F. Hickey, and J. G. Zeikus. 1991. Formate Synthesis from Hydrogen by Hydrogen Utilizing Methanogens. Annual Meeting of the American Society for Microbiology.

3. Podkovyrov, S., and J. G. Zeikus. 1992. Purification and Characterization of Phosphoenol-pyruvate Carboxykinase from Anaerobiospirillum succiniciproducens. Annual Meeting of the American Society for Microbiology.

\section{PRESENTATIONS}

August, 1990. "Regulation of Solventogenesis in CAB by bioelectrochemical controls of $\mathrm{H}_{2}$ and Organic Acid Metabolism" International Workshop on the Regulation of Metabolism, Genetics, and Development of the Solvent-Forming Clostridia, Salisbury, England.

September, 1990. "Physiological Control of Oxychemical Fermentations: Enhanced Production of Alcohols and Methane by Anaerobic Bacteria." Biomass and Production Session, IUMS Congress: Bacteriology \& Mycology, Osaka, Japan. 
October, 1990. "Emerging Microbial Enzyme Technologies for Utilization of Renewable Resources", Texas Biotechnology Symposium, University of Texas, Austin, Texas.

October, 1991. "Emerging Microbial and Enzyme Technologies for Renewable Resource Utilization", University of Nebraska, Lincoln, Nebraska.

October, 1991. "Emerging Microbial and Enzyme Technology for Renewable Resource Utilization", invited presentation, Symposium on Biotechnology and the Bacterial Cell, Michigan State University, East Lansing, Michigan.

November, 1991. "Emerging Microbial and Enzyme Technologies for Renewable Resource Utilization", American Sociedty for Microbiology Southeast Branch Meeting, Atlanta, Georgia.

\section{STUDENTS TRAINED}

1. Dr. Jer-Song Shieh, Completed postdoctorate

2. Dr. Wei-Min Wu, Completed doctorate

3. Dr. Susan Lowe, Current postdoctorate

4. Dr. Sergey Podkovyrov, Current postdoctorate

5. Dr. Bassam Annous, Current postdoctorate 

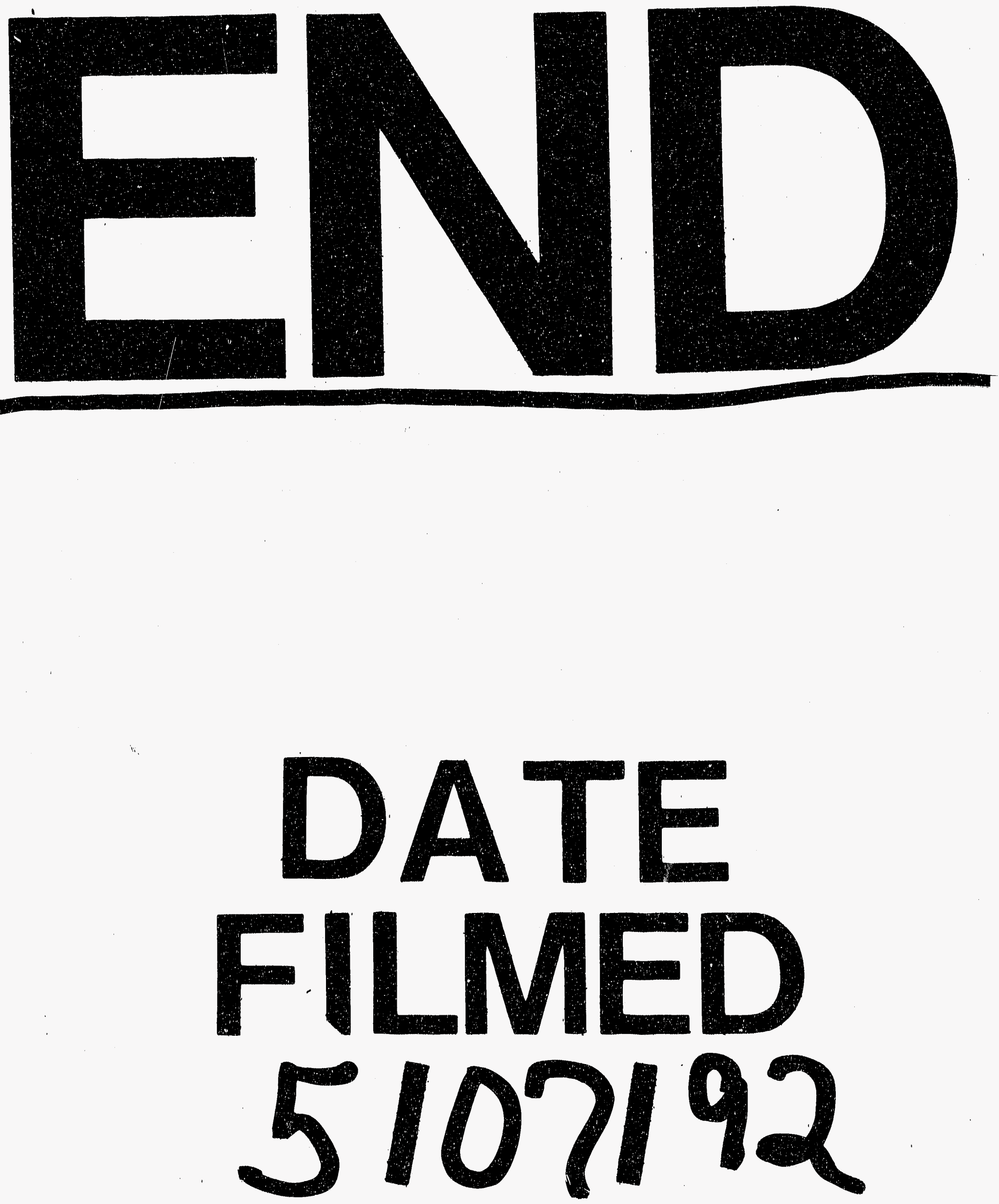
<smiles>C1C[Tl]1</smiles>

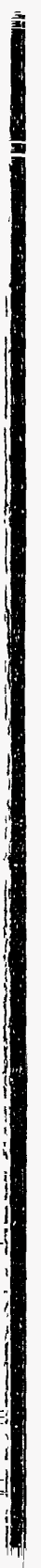

